\title{
Peningkatan Hasil Belajar Kelistrikan Otomotif Menggunakan Alat Peraga Sistem Pengapian Konvensional Pada SMK 45 Kota Bima
}

\author{
Raden Nasuhi \\ SMK 45 Kota Bima \\ Radennasuhi45@gmail.com
}

\begin{abstract}
ABSTRAK
Penelitian ini bertujuan untuk meningkatkan hasil belajar siswa dengan menggunakan alat peraga sistem pengapian konvensional. Metode penelitian yang digunakan adalah eksperiment, dengan populasi siswa Sekolah Menengah Kejuruan 45 Kota Bima jurusan teknik mesin yang terdiri dari 36 siswa. hasil penelitian menunjukan bahwa ada peningkatan hasil belajar kelistrikan otomotif dengan menggunakan alat peraga sistem pengapian konvensional. dengan nilai rata-rata (pre-test) sebesar 56,11 dan nilai rata-rata setelah menerapkan pembelajaran menggunakan alat peraga sistem pengapian (post-test) sebesar 73,33. sehingga terjadi peningkatan 30,68\% dapat dikatakan bahwa penggunaan alat peraga sistem pengapian konvensional pada matapelajaran kelistrikan otomotif telah berjalan dengan baik setelah menggunakan alat peraga sistem pengapian. Hal ini memberikan bukti bahwa ada peningkatan (taraf signifikan 5\%) hasil belajar Kelistrikan Otomotif dengan menggunakan alat peraga sistem pengapian konvensional pada siswa SMK 45 Kota Bima Jurusan Tekhnik Mesin.
\end{abstract}

Kata kunci: Alat Peraga, Sistem Pengapian, Pembelajran, Kelistrikan Otomotif 


\section{PENDAHULUAN}

Menurut webset's New World Dictionary (1962) Pendidikan adalah proses pelatihan dan pengembangan pengetahuan, ketrampilan, pikiran, karakter dan seterusnya lewat persekolahan formal. Pemahaman mengenai pendidikan mengacu pada konsep tersebut menggambarkan bahwa pendidikan memiliki sifat dari sasarannya yaitu manusia (Syaiful Sagala 2011:1). Proses belajar mengajar merupakan aktivitas antara guru dan siswa di dalam kelas. Dalam proses itu terdapat proses pembelajaran yang berlangsung akibat penyatuan materi, media, peneliti, siswa dan kontek belajar.

Untuk mendapat suatu pencapaian pengetahuan yang diharapkan maka diperlukan suatu komunikasi yang baik antara guru dengan siswa, RPP yang dibuat hendakanya dapat menarik perhatian siswa sehingga bisa optimal. Dalam pengajaran metode yang sering digunakan adalah metode ceramah dimana metode ceramah adalah metode yang menyampaikan materi dengan cara penuturan dan penjelasan secara lisan, sedangakn metode ini di anggap pasif dikarenakan siswa pada saat mengikuti proses belajar hanya menjadi pendengar ceramah dan melihat gambar yang di sajikan tanpa melakukan sendiri apa yang di sampaikan oleh guru. Sehingga siswa akan menjadi pasif, tidak mendapatkan kesan, ketrampilan dan pengalaman dari pembelajaran. Dalam metode ceramah siswa hanya akan mampu menghafal teori, Karena siswa tidak berperan langsung sebagai pelaku aktif dalam proses belajar mengajar.

Belajar merupakan suatu proses kegiatan dan buan suatu hasil atau tujuan. Dimana sebuah pengalaman sendiri dapat mengkonstruksi pengetahuan kemudian memberi makna pada pengetahuan itu. Melalui proses belajar yang dialami langsung akan menciptakan suasana serius tapi santai dan santai tapi serius karena dalam proses belajar mengajar harus tercipta pembelajaran yang menyenangkan.

Sudjana (1989:9) menegaskan bahwa pembelajaran akan efektif apabila objek dan kejadian yang menjadi bahan pembelajaran dapat divisualkan secara realistik menyerupai keadaan sebenarnya, namun tidak berarti bahwa alat peraga itu harus menyerupai keadaan yang sebenarnya. Fungsi alat peraga bukan hanya alat bantu, namun juga merupakan alat pembawa informasi yang dibutuhkan siswa untuk mengenal komponan yang real sesuai dengan materi yang disampaikan. Kemampuan dan minat siswa dalam pembelajaran kelistrikan otomotif sangat diperlukan agar memperlancar proses pembelajaran. Dalam rangka menarik perhatian dan minat siswa dalam proses pembelajaran sistem pengapian, maka peneliti akan melakukan pembelajaran dengan menggunakan alat peraga sistem pengapian konvesional. 


\section{METODE PENELITIAN}

Penelitian ini menggunakan desain eksperimen yang semu atau Quasi Eksperiment dengan pola pre test - post test. Dalam penelitian ini peneliti menggunakan dua kelompok, yaitu kelompok Eksperiment dan kelompok Kontrol, dimana kelompok Eksperiment mendapatkan perlakuan sedangkan kelompok kontrol tidak diberikan perlakuan. Dua kelompok tersebut dianggap sama dalam segala aspek yang relevan dan perbedaan hanya terdapat dalam perlakuan. Dalam penelitian ini peneliti menggunakan dua kelas sebagai kelas Eksperiment dan kelas kontrol.

Populasi yang digunakan dalam penelitian adalah Siswa SMK 45 Kota Bima, peneliti mengamil satu kelas yang berjumlah 18 siswa untuk kelas eksperiment dan satu kelas yang berjumlah 18 siswa untuk kelas kontrol.

Variabel penelitian adalah obyek penelitian atau sesuatu yang menjadi titik perhatian suatu penelitian. Jadi variabel dalam penelitian ini yaitu hasil belajar siswa pada kemampuan pemahaman komponen, mendiagnosis dan cara kerja sistem pengapian konvensional dengan menggunakan alat peraga.

\section{HASIL DAN PEMBAHASAN}

HASIL

Sebelum menerapkan proses pembelajaran dengan alat peraga sistem pengapian konvensional untuk kelompok eksperimen, terlebih dahulu di lakukan pre-test untuk mengetahui kemampuan awal siswa, dari pelaksanaan pre-test tersebut diperoleh hasil pada tabel 1 .

Tebel 1. Hasil Pre-Test

\begin{tabular}{lcc}
\hline Kelompok & Kontrol & Eksperiment \\
\hline Minimum & 40 & 40 \\
Maksimal & 65 & 70 \\
Rata-rata & 54,17 & 56,11 \\
\hline
\end{tabular}

Berdasarkan tabel 1 dapat disimpulkan bahwa antara kelompok kontrol yang akan diberikan pembelajaran konvensional dan kelompok eksperiment yang akan diberikan pembelajaran dengan alat peraga sistem pengapian konvensional memiliki kemampuan awal yang tidak jauh berbeda maka penelitian dapat dilaksanakan.

Setelah peserta didik mendapatkan perlakuan dengan proses pembelajaran konvensional untuk kelompok kontrol dan alat peraga sistem pengapian konvensioanl untuk kelompok eksperiment, maka dilakukan post-test untuk mengetahui kemampuan peserta didik 
setelah mendapatkan pembelajaran dengan kedua proses tersebut. Dari pelaksanaan post-test diperoleh hasil pada tabel 2.

Tabel 2. Hasil Post-Test

\begin{tabular}{lcc}
\hline \multicolumn{1}{c}{ Kelompok } & Kontrol & Eksperiment \\
\hline Minimum & 60 & 60 \\
Maksimal & 75 & 85 \\
Rata-rata & 67,5 & 73,33 \\
Standar deviasi & 5,57 & 6,64 \\
\hline
\end{tabular}

Berdasarkan tabel 2 diperoleh rata-rata kelompok eksperiment yang akan diberikan pembelajaran convensional yang dilengkapi alat bantu berupa alat peraga sistem pengapian konvensional lebih baik dibbandingkan dengan rata-rata kolompok kontrol yang hanya diberikan pembelajaran ceramah saja $(73,33>67,5)$.

Hasil deskriptif skor rata-rata kemampuan awal (pre-test), skor rata-rata kemampuan akhir (post-test) dan peningkatan kemampuan peserta didik dalam memahami materi kelistrikan otomotif antara kelompok kontrol yang diberikan pembelajaran konvensional dan kelompok eksperimet yang diberikan pembelajaran dengan alat peraga sistem pengapian konvensional dapat dilihat pada tabel 3.

Tabel 3. Hasil Peningkatan Rata-rata kemampuan siswa

\begin{tabular}{|c|c|c|}
\hline Kelompok & Kontrol & Eksperiment \\
\hline $\begin{array}{l}\text { Rata-rata Pre- } \\
\text { test }\end{array}$ & 54,17 & 56,11 \\
\hline $\begin{array}{l}\text { Rata-rata Post- } \\
\text { test }\end{array}$ & 67,50 & 73,33 \\
\hline Peningkatan & 13,33 & 17,22 \\
\hline Persentase & $24,6 \%$ & $30,68 \%$ \\
\hline
\end{tabular}

Berdasarkan tabel 3 dapat dilihat bahwa kelompok eksperiment yang mendapatkan proses pembelajaran dengan alat peraga sistem pengapian konvensioanal kemampuannya dalam memahami materi sistem pengapian meningkat sebesar 17,22 atau 30,68\% sedangkan kelompok kontrol yang mendapatkan proses pembelajaran konvensional kemampuannya meningkat sebesar 13,32 atau 24,6\%. Dengan demikian peningkatan kemampuan siswa SMK 45 Kota Bima dalam memahami materi sistem pengapian yang mendapat proses pembelajaran dengan alat peraga sistem pengapian konvensional lebih tinggi dibandingkan dengan kelas yang memdapatkan proses pembelajaran konvensional.

Dari hasil perhitungan homogenitas didapat varian untuk kelompok eksperimen $=44,12$ dan $\mathrm{dk}=18-1=17$. Hasil perhitungan menunjukkan varians kelompok kontrol = 33,08 dan $\mathrm{dk}=18-1=17$. Dari perbandingan keduannya diperoleh $\mathrm{F}_{\mathrm{hitung}}=1,33$ dengan taraf signifikan 
$5 \%$. Dk pembilang $=17$, dan $\mathrm{dk}$ penyebut $=17$, maka diperoleh $\mathrm{F}_{\text {tabel }}=2,27$. Dengan demikian bahwa $F_{\text {hitung }}<\mathrm{F}_{\text {tabel }}(1,33<2,27)$ sehingga Ho diterima, jadi kedua sampel mempunyai varians yang sama (homogen).

Dari perhitungan didapat rata-rata kelompok eksperiment $=73,33$ dengan varians $=$ 44,12 dan jumlah siswa 18 orang. Rata-rata untuk kelompok kontrol = 67,50 dengan varians $=33,08$ dan jumlah siswa 18 orang. Sehingga diperoleh $t_{\text {hitung }}=3,32$. Dengan taraf signifikan $5 \%$ dan $\mathrm{dk}=(18+18)-2=34$ diperoleh $\mathrm{t}_{\text {tabel }}=2,73$. Hal ini menunjukan $3,32>2,73\left(\mathrm{t}_{\text {tabel }}>\right.$ $t_{\text {hitung }}$ ) sehingga dapat disimpulkan bahwa rata-rata kelompok eksperimen lebih besar dari pada rata-rata kelompok kontrol. Hal ini menunjukan adanya perbedaan rata-rata antara kelompok eksperiment dan kelompok kontrol.

Hasil analisis $t$-test yang telah dilakukan didapat rata-rata perbedaan post test antara kelompok kontrol dan kelompok eksperiment $=6,21$ dan subyek 18, maka diperoleh $\mathrm{t}_{\text {-hitung }}=$ 3,32. Dengan taraf signifikan 5\% dan $\mathrm{dk}=18-1=17$ diperoleh $\mathrm{t}_{\text {-tabel }}$ 2,73. Dengan demikian 3,32 > 2,73 ( $\mathrm{t}_{\text {-hitung }}>\mathrm{t}_{\text {-tabel }}$ ), maka Ho ditolak dan Ha diterima, sehingga dapat disimpulkan bahwa melalui pembelajaran dengan menggunakan alat peraga dapat meningkatkan hasil belajar siswa.

\section{PEMBAHASAN}

Sebelum adanya perlakuan terhadap kelompok eksperiment dan kelompok kontrol, keduannya diberikan pre-test terlebih dahulu, untuk mengetahui kemampuan awal dari peserta didik yang akan di cadikan objek penelitian. Hasil perhitungan awal kedua kelompok berasal dari distribusi normal dan mempunyai varians yang sama (homogen). Hal ini memnunjukan bahwa sebelum adanya perlakuan, kedua sampel tersebut berasal dari kondisi yang sama.

Berawal dari kondisi yang sama, kedua kelompok kemudian di berikan perlakuan yang berbeda yaitu, kelompok kontrol di berikan perlakuan melalui pembelajaran konvensional yaitu ceramah sedangkan kelompok eksperiment diberi perlakuan pembelajaran melalui alat peraga sistem pengapian. Pada akhir proses pembelajaran kedua kelompok tersebut diberi post test sebagai evaluasi pembelajaran.

Peningkatan hasil belajar dengan menggunakan alat peraga sistem pengapian mengalami peningkatan. Hal ini diperoleh rata-rata kemampuan awalnya mencapai 56,11 dan setelah pembelajaran menjadi 73,33. Menunjukan adanyapeningkatan hasil belajar yang nyata setelah mengikuti pembelajaran dengan menggunakan alat peraga sistem pengapian. 
Peningkatan hasil belajar ini mencapai $30,68 \%$ sedangkan rata-rata awal pada kelompok kontrol mencapai 54,17 dan setelah pembelajaran rata-rata mencapai 67,5. Dalam hal ini menunjukan adanya peningkatan hasil belajar yang nyata dari kelompok kontrol, peningkatan hasil belajar ini mencapai 24,6\%. Berdasarkan hasil uji peningkatan hasil belajar dari kedua kelompok tersebut berbeda, peningkatan hasil belajar kelompok eksperiment mencapai $30,68 \%$ jauh lebih besar dibandingkan kelompok kontrol sebesar 34,6\%, hal ini berarti bahwa hasil belajar kelistrikan otomotif dengan menggunakan alat peraga sistem pengapian lebih baik dibandingkan pembelajaran konvensional.

\section{KESIMPULAN}

Terbukti bahwa ada peningkatan hasil belajar kelistrikan otomotif dengan menggunakan alat peraga sistem pengapian konvensional pada siswa SMK 45 Kota Bima, dengan taraf signifikan 5\% dan $t_{\text {hitung }}>t_{\text {tabel }}, 3,32>2,73$. Nilai rata-rata post-test control sebesar 67,50 dan nilai rata-rata post test eksperiment sebesar 73,33 yang menunjukan peningkatan sebesar 5,83.

\section{DAFTAR PUSTAKA}

Arikunto, S. (2010). Dasar-dasar Evaluasi Pendidikan. Jakarta: Bumi Aksara Sagala, Syaiful. (2011). Konsep dan makna Pembelajaran. Bandung : Alfabeta Sugiyono. (2007). Statistika Untuk Penelitian. Bandung : Alfabeta.

Sudjana. (1989). Desain dan Analisis Eksperiment. Bandung : Tarsito Sudjana. (1989). Metode Statistika. Bandung : Tarsito 